\title{
The development of an anti-corruption education module from a contextual perspective in higher education
}

\author{
M. Zakiyah*, P.K. Wulandari \& P.K. Dewi \\ University of Brawijaya, Malang, Indonesia
}

\begin{abstract}
Indonesia has been attempting to stop corruption. This effort is in the level of prevention from a legal perspective. However, the fighting towards corruption should be approached from a social-cultural perspective. This study was conducted at the center of character building. The outcome of this study was to compose a module on anti-corruption education from a contextual perspective. Contextual perspective was used due to (1) meaningful approach, the student could build their knowledge from their experience; (2) direct the student to be the honest and caring generation. The result of the module development is the content of four-chapters of (1) corruption from law, religion, politics, socio-culture, and the ethics of Pancasila; (2) building self-integrity and following the footsteps of the founding fathers; (3) student as the agent of anti-corruption; (4) conclusion. Each chapter are also accompanied by the learning aims, learning materials, and tasks
\end{abstract}

Keywords: module, anti-corruption education, contextual perspective

\section{INTRODUCTION}

Corruption is a major problem in Indonesia. In 2020, it was revealed that the biggest corruption case of PT Asuransi Jiwasraya (Persero) had caused the state to lose more than 13.7 trillion (Hardiyanto 2020). Ironically, all 40 suspects of the corruption case in 2018 involving members of the Malang City DPRD, have yet to be prosecuted. Besides, the revision of the Corruption Eradication Commission Law (KPK Law) issued by the legislative body (DPR) around October 2019 made the public anxious and led to protests in several cities. Public fear is the potential for the emergence of articles that weaken the KPK, such as the DPR which recommends revoking the investigative and prosecutorial powers that have been the strength of the KPK in eradicating corruption. Yulianto \& Zakiyah (2018) explain that the formation of the KPK is still limited to anti-corruption measures and has several weaknesses, such as injustice in the criminal justice of corruption, fines and repayments of state cash that are not proportional to the number of state losses, and the lack of national integrity in fighting corruption. Thus, support from all parties including academics as agents of preventing acts of corruption is needed.

What needs to be appreciated is that awareness of the prevention and eradication of corruption by Indonesia has produced few positive results. According to the 2018 Transparency International (TI) survey among ASEAN countries, Indonesia's Corruption Perception Index (CPI) was in 4th place with 38 points on a $0-100$ scale, 1 point higher than the previous year and was able to shift Thailand's position. Even though it has not been able to occupy the top position, it can be a positive signal in efforts to prevent and eradicate corruption in a sustainable manner (Transparency International in BPS 2018).

Furthermore, Wijoyanto in Sofia (2011) revealed several approaches to action against corruption, namely: a lawyer approach, a business approach, a market/economic approach, and a socio-cultural

${ }^{*}$ Corresponding Author 
approach. As academics, we have a responsibility to participate in fighting corruption by pursuing a socio-cultural approach.

Kadir (2013) argues that anti-corruption learning still focuses on a legal approach. Thus, learning innovations that are more interesting and able to raise students' awareness and encourage them to have an attitude of anti-corruption are needed. Contextual Teaching and Learning (CTL) is considered appropriate to be one of the innovations in anti-corruption education because it provides opportunities for students to seek their own experiences in the field. Students not only learn things that are cognitive, but this learning is directed to touch the affective realm so that they are able to build student character.

In implementing CTL, researchers initiated the development of an anti-corruption module to make it easier for researchers to apply this approach on students. The development of an anticorruption module with a contextual perspective, in addition to containing material on corruption, is complemented by instructions on how students seek experience in the field regarding actions that are allegedly leading to corruption. The development of the anti-corruption module will be integrated in the General Compulsory Subject (MKWU), especially Citizenship and Indonesian Language Education at Brawijaya University. The development of the anti-corruption module with contextual insight is expected to be able to contribute to building the character of anti-corruption integrity to UB students.

\section{METHODS}

This study uses the Borgh \& Gall development model (1983 in Silalahi 2017) with four core research stages, namely (1) the pre-development stage, (2) the development stage, (3) the trial stage, and (4) the revision stage. The research, which is located at Brawijaya University, began with a predevelopment stage consisting of a preliminary analysis and analysis of student characteristics. The development stage was modeling. The trial phase was small group trials for Universitas Brawijaya students who were taking Indonesian Language or Citizenship Education courses. The revision stage is model revision activities and the preparation of the final product (Table 1).

Table 1. Score achievement actions.

\begin{tabular}{ll}
\hline Value & Actions \\
\hline $85-100$ & $\begin{array}{l}\text { Implementation, meaning that there is no need for revision. Revisions are only in the form of } \\
\text { minor revisions as suggested by the validator. }\end{array}$ \\
$70-84$ & $\begin{array}{l}\text { Implementation with a few revisions based on notes of test subjects. } \\
55-69\end{array}$ \\
$\begin{array}{l}\text { The revisions are based largely on the notes of test subjects. } \\
\text { Big revision. Researchers can replace or change the aspects presented in teaching materials. }\end{array}$
\end{tabular}

\section{RESULTS AND DISCUSSION}

\subsection{Description of the contextually informed anti-corruption module}

As stated in the introduction, this research aims to produce an anti-corruption module based on contextual learning. Zulfa (2019) states that contextual learning is one of strategies used for learning values, especially life values in society. This study focuses on student-oriented learning. The students should find the related concept or theory and compare it to the real world. Therefore, this would affect the student's psychomotor to absorb the good value in their life (Sanjaya 2006; Suyanti 2010 in Sinaga \& Silaban 2020). Contextual learning seems to be the right choice to apply anti-corruption education. It is believed that the students would be the dynamo of social integrity.

In order to develop an anti-corruption module based on contextual learning, seven components of contextual learning were used, namely: constructivism, inquiry, questions, learning community, 
modeling, reflection, and authentic assessment. In order to realize these seven components, this module is presented in four chapters. The first chapter presents "Corruption in the Perspective of Law, Religion, Politics, Socio-Culture and Pancasila Ethics". This chapter discusses the nature of corruption from various perspectives. In this presentation, even though it is cognitive, students will be asked to build their own understanding of the criminal act of corruption (constructivism) through practice questions. The understanding that exists in students so far will be strengthened by the theory in chapter one and the practice questions in this chapter. Furthermore, in chapter II, it discusses "Building Self Integrity and Emulating National Teachers". In this chapter, examples of national teachers and internalization of anti-corruption values are presented as modeling. Students are expected to get models or examples of anti-corruption figures from the nation's teachers. In order to strengthen the impression of modeling, in the training section students are asked to look for millennial models as anti-corruption figures who can inspire them.

Furthermore, chapter III discusses "Students as Anti-Corruption Agents (Inquiry-Based Case Analysis Model)" This chapter embodies the components of inquiry, learning community, questions, and authentic assessment. In this chapter, students are asked to carry out field investigations related to the misuse of service procedures around them. Students are expected to discover by themselves (inquiry) the misuse of service procedures that is the forerunner of corruption or mini corruption. This activity was originally carried out in groups so as to include a learning community component and an authentic assessment because students will be asked to evaluate and assess the results of their own and other groups' fieldwork. This activity will certainly give students experience to ask questions both to themselves, to the team, as well as to the servants (community/campus service providers).

This module has components for each chapter in the form of (1) learning objectives, (2) material, and (3) exercises. The learning objectives of the first chapter are (1) explaining corruption from a legal perspective, (2) explaining anti-corruption from a religious perspective, (3) describing corruption in the circle of law and power, (4) describing the anti-corruption culture and social sanctions, and (5) presenting Pancasila ethics and attitudes of corruption. This objective is consistent with the learning material which contains (1) introduction, (2) corruption from a legal perspective, (3) anti-corruption from a religious perspective, (4) anti-corruption culture and social sanctions, and (5) Pancasila ethics and corruption attitudes. To be able to measure learning achievement, the exercise at the end is arranged in the form of questions that show the reasons for the occurrence of criminal acts of corruption. From here, it will be seen that the building of students' understanding of the criminal act of corruption and the reasons that can be related to the perspective of law, religion, Pancasila ethics and anti-corruption attitudes, to why there is an anti-corruption culture.

To demonstrate students' understanding of the nature of corruption, the first chapter begins with a question on student understanding. This question also serves as the foundation for constructivism, that students build their understanding of corruption on the building of their previous understanding.

Furthermore, Chapter II has learning objectives as follows: explaining the value of anticorruption and character education in UB, internalizing religious values (Islam), internalizing socio-cultural values, internalizing anti-corruption values in Pancasila, and imitating the nation's teachers. The material in this chapter is in accordance with the learning objectives. The exercises in this chapter are in the form of exercises to relate theories that have been studied with realities in the field, such as that religion teaches anti-corruption values, but there are figures known to be religious who are involved in criminal cases of corruption. Students are also asked to look for cultural norms that have the potential to foster a culture of corruption, cultural norms that can be used as sanctions for criminal acts of corruption and which can be used as preventive measures for corruption, and finally look for millennial figures who are considered capable of becoming anti-corruption figures.

To be able to explore students 'initial understanding, this chapter is presented with opening questions that can explore students' understanding of corruption in cultural, social, and religious norms, internalization of anti-corruption values, and national figures with high integrity. This question ensures that the new understanding constructs built in this chapter build on students' initial understanding of the material taught in this chapter. 
Furthermore, the learning objectives in chapter III are describing the concept of contextual learning, connecting contextual learning and anti-corruption education, and conducting reporting and investigations. The material in this chapter discusses and invites students to carry out these learning objectives. The exercises in this chapter are in the form of investigative reports on allegations of abuse of service procedures around students. This exercise is also a form of inquiry, learning community, authentic assessment, and questions in contextual learning. To ensure that their understanding is constructive, this chapter begins with questions about students' knowledge so far about contextual learning, the potential for contextual learning as anti-corruption education, and investigative reporting practices.

The final chapter is Reflections and Closing. This chapter provides the opportunity for students to write and reflect on what they have done. This includes reflections on findings in the field. From this reflection, students are asked to rewrite the learning experiences they have gained through this activity, construct a new understanding of the criminal act of corruption, so that it is hoped that there will be an internalization of anti-corruption values embedded in the minds of students. Exercises at the reflection stage are also exercises used in the pretest and posttest to measure the effectiveness of the module.

\subsection{Refinement of the contextually informed anti-corruption module}

To be able to assess the feasibility of this contextual learning-based anti-corruption module, a validation test was then carried out on two experts, namely the module development expert and the anti-corruption study expert. Experts in developing focus modules assess the contextual aspects of learning, presentation, content, and the language used in this module. Meanwhile, anti-corruption research experts focus on corruption and anti-corruption material, presentation, and the language used.

After that, the module was revised based on the expert test results. The module will also be tested for its effectiveness in small groups online given the pandemic conditions that limit the possibility of face-to-face becoming virtual ones.

The following is the recapitulation of expert validation test scores on the anti-corruption module based on contextual learning which is presented in Table 2 .

Table 2. The recapitulation of validation test scores on the anti-corruption module based on contextual learning.

\begin{tabular}{lllll}
\hline No & Validator & $\boldsymbol{x}$ & $\mathbf{\%}$ & Note \\
\hline 1. & Anti-corruption studies expert & 2.95 & $73.8 \%$ & Valid \\
2. & Module development experts & 3.33 & $83.4 \%$ & Valid \\
3. & Students & 3.43 & $85.8 \%$ & Very Valid \\
& Average & 3.24 & $81 \%$ & Very Valid \\
\hline
\end{tabular}

Based on expert judgment, this module has been declared valid. The average score of all aspects based on the expert's assessment of anti-corruption studies is 2.95 with a percentage of $73.8 \%$. This means that this teaching material is valid and feasible to be implemented with several revisions according to the direction of the expert. Meanwhile, based on the expert's judgment, the preparation of this teaching material module got an average score of 3.34 with a percentage of $83.4 \%$. This means, as the results of the assessment of the anti-corruption study expert, this module is feasible to be implemented and is valid by making several revisions according to the expert's notes. Based on students' judgment, this module got a score 3.43 or $85.5 \%$ in percentage. The total score of the two experts in all aspects is 3.24 with a percentage of $81 \%$ which indicates that this module is very valid and feasible to be implemented with several revisions.

Furthermore, based on each aspect, here are the results of the validator's assessment of the contextual learning-based anti-corruption module. In the contextual aspect of learning, the following is a recapitulation of expert judgment which is presented in Table 3. 
Table 3. The score of contextual learning's aspect.

\begin{tabular}{llllr}
\hline No & Validators & $\boldsymbol{x}$ & \% & Note \\
\hline 1. & Anti-corruption studies expert & 2.85 & $71.4 \%$ & Valid \\
2. & Module development experts & 3.31 & $82.8 \%$ & Valid \\
& Average & 3.08 & $77.1 \%$ & Valid \\
\hline
\end{tabular}

Based on the results of the recapitulation of anti-corruption study experts, the contextual learning aspects of this module are rated on average 2.85 with a percentage of $71.4 \%$. This means, according to an anti-corruption study expert, this module is valid and feasible to be implemented with revisions in several parts, such as adding cases close to students. According to module development experts, this module is rated at an average of 3.31 with a percentage of $82.8 \%$. This means that this module is valid and feasible to be implemented with several revisions.

In the presentation aspect, a recapitulation of expert judgment can be seen in Table 4 .

Table 4. The score of presentation aspect.

\begin{tabular}{lllll}
\hline No & Validator & $\boldsymbol{x}$ & $\mathbf{\%}$ & Note \\
\hline 1. & Anti-corruption studies expert & 2.88 & $72 \%$ & Valid \\
2. & Module development experts & 3.68 & $92 \%$ & Very Valid \\
3. & Students & 3.4 & $85 \%$ & Very valid \\
& Average & 3.32 & $83 \%$ & Very Valid \\
\hline
\end{tabular}

Based on the expert's assessment of anti-corruption studies, this module gets an average score of 3.6 with a percentage of $72 \%$. This means that this module is valid and feasible for implementation with revisions according to the notes, such as the preparation of modules which are judged to begin with abstract (difficult) material to concrete (easy) material. Even so with the module development experts who rated an average of 4.6 and a percentage of $92 \%$ for the presentation of this module. This shows that this module is very valid and feasible to be implemented with a limited revision, if necessary. Based on students' judgment, this module got a score 3.4 or $85 \%$ in percentage. In the aspect of module content, the following is a recapitulation of the assessment of the anti-corruption study expert and the module development exper can be seen at Table 5 .

Table 5. The score of modul content's aspect.

\begin{tabular}{lllll}
\hline No & Validator & $\boldsymbol{x}$ & $\mathbf{\%}$ & Note \\
\hline 1. & Anti-corruption studies expert & 2.96 & $74.2 \%$ & Valid \\
2. & Module development experts & 3.31 & $82.8 \%$ & Valid \\
3. & Students & 3.38 & $84.6 \%$ & Very valid \\
& Average & 3.21 & $80.4 \%$ & Valid \\
\hline
\end{tabular}

Based on the recapitulation, the anti-corruption study experts considered that this module was valid with a value of 2.96 and a percentage of $74.2 \%$, which means that it is feasible to be implemented with several revisions. According to module development experts, this module is in the valid category with a value of 3.31 with a percentage of $82.8 \%$. Based on students' judgment, this module got a score 3.38 or $84.6 \%$ in percentage. This means that this module is worth implementing with several revisions. 
In the language aspect, a recapitulation of the assessment of the anti-corruption study expert and the module development expert can be seen at Table 6 .

Table 6. The score of language aspect.

\begin{tabular}{lllll}
\hline No & Validator & $\boldsymbol{x}$ & $\mathbf{\%}$ & Note \\
\hline 1. & Anti-corruption studies expert & 3.28 & $80 \%$ & Valid \\
2. & Module development experts & 3 & $75 \%$ & Valid \\
3. & Students & 3.52 & $88 \%$ & Very Valid \\
& Average & 3.24 & $81 \%$ & Very Valid \\
\hline
\end{tabular}

Based on the results of the recapitulation of the language aspects, it is known that the anticorruption study experts assess that this module is valid and feasible to be implemented with several revisions with an average value of 3.28 and a percentage of $80 \%$. Meanwhile, according to the module development expert, the language in this module received an average score of 3 with a percentage of $75 \%$. Meanwhile, students' judgement for this module got a score 3.52 or in percentage $88 \%$. This means that this module is very valid and the service is implemented with several revisions to the language aspect.

Based on the test results from the anti-corruption study expert, there are several notes and revisions that must be made, which include typos, incorrect use of terms, and theoretical errors. In fact, invalid laws are no longer called laws. There are also statements that there are laws that are no longer valid and that other laws are removed, even though these laws are still valid. False statements or theoretical justifications are thus eliminated. Furthermore, there is input to add female teacher figures. In this case, revisions were made by adding female figures, such as "Najwa Shihab" who was concerned about guarding suspected corruption cases in Indonesia. Additionally, according to the expert, this module is structured from abstract/difficult to concrete/easy. In fact, the principle of developing modules is to start from the easy ones to the difficult ones. For this, the module composition is rearranged so that it goes from easy to difficult. Finally, according to the expert, this module needs to be added to cases more relevant to students. Therefore, this module will add examples that are close to students.

Based on the validation test on module development experts, there are several notes. First, the use of language errors, such as the misuse of the conjunction "then" at the beginning of a sentence and the use of the pronoun "this" should be "that". For language errors, revisions are made according to the direction of the expert. Second, the systematic error/sequence of the arrangement of chapters, as in chapter I points $\mathrm{C}$ and $\mathrm{D}$, which according to experts should be reversed. In this error, revisions are made by following expert input. According to the module development expert, the contextual learning-based anti-corruption module is interesting because it uses a variety of study perspectives to analyze corruption studies

\section{CONCLUSIONS}

The specification of the contextual learning-based anti-corruption module contains four chapters, namely (1) Corruption in the Perspective of Law, Religion, Politics, Socio-Culture and Pancasila Ethics, (2) Building Self Integrity and Emulating National Teachers, (3) Students as Anti-Corruption Agents (Case-Based Analysis Model Inquiry), and (4) Reflection and Closing. Each chapter is equipped with learning objectives, materials, and exercises. This module uses seven components of contextual learning, namely constructivism, inquiry, questions, learning community, modeling, reflection, and authentic assessment. Constructivism is developed in each chapter in the form of questions related to student understanding before studying the material in each chapter. Inquiry, questioning, learning community, and authentic assessment are developed in Chapter III. Modeling 
is developed in chapter II. Meanwhile, reflection is developed in chapter IV. Based on product development and validation tests from anti-corruption studies experts and module development experts, the contextual learning-based anti-corruption module is considered valid and feasible to be implemented with several revisions.

\section{REFERENCES}

Hadin, A.F. \& Pahlevi, R. 2016. Desain bahan ajar pendidikan kewarganegaraan berbasis pendidikan anti korupsi di perguruan tinggi. Jurnal Moral Kemasyarakatan 1(2): 162-172.

Hanoum, R.N. 2014. Mengembangkan keterampilan berpikir tingkat tinggi mahasiswa melalui media sosial. Edutech, 13(3): 400-408.

Hardiyanto, S. 2020, Selain jiwasraya, berikut kasus korupsi terbesar di indonesia.

Kadir, A. 2013. Konsep pembelajaran kontekstual di sekolah. Jurnal Dinamika Ilmu 13(1):17-38.

Krathwohl, D.R. 2002. A revision of Bloom's taxonomy: An overview. Theory into Practice 41(4): 212-218.

Sanjaya, W. 2006. Strategi pembelajaran berorientasi standar proses pendidikan. Jakarta: Kencana Prenada Media Group.

Saripudin, D. \& Komalasari, K. 2016. Culture-based contextual social studies learning for development of social and cultural values of junior high school students. The Social Sciences 11(23): 5726-5731.

Schunk, D.H. 2012. Learning theories: An educational perspective. 6th Edn. New York: Pearson Education.

Silalahi, A. 2017. Development research (penelitian pengembangan) dan research \& development (penelitian \& pengembangan) dalam bidang pendidikan/pembelajaran. (Unpublished Dissertation) on doctoral program Universitas Negeri Medan.

Sinaga, M. \& Silaban, S. 2020. Implementasi pembelajaran kontekstual untuk aktivitas dan hasil belajar kimia siswa.Jurnal Gagasan Pendidikan Indonesia 1(1): 33-40

Sofia, A.I. 2011. Model pembelajaran mata kuliah anti-korupsi. dalam pendidikan antikorupsi untuk perguruan tinggi. Jakarta: Kemdikbud.

Transparansi Internasional. Corruption perceptions index. (Online).

Trianto. 2009. Mendesain model pembelajaran inovatif progresif. Surabaya:Kencana.

Wicaksono, S.R. 2011. Strategi penerapan domain afektif di lingkup perguruan tinggi. Jurnal Pendidikan 2(2) September 2011: 112-119.

Yulianto \& Zakiyah, M. 2018. Reaktualisasi Zuhud Al Ghazali sebagai model pendidikan antikorupsi pada pendidikan anak usia dini dan dasar. proceeding on international seminars Al Ghazali, Jakarta, January 18, 2018.

Zulfa. 2019. Pembelajaran kontekstual nilai-nilai karakter mata kuliah budaya Minangkabau sebagai penguatan identitas kebangsaan. Journal Moral and Civic Education 3(1): 38-47 